\title{
Expression pattern and ontogenesis of thyroid hormone receptor isoforms in the mouse heart
}

\author{
I Stoykov ${ }^{1,2}$, B Zandieh-Doulabi ${ }^{1}$, A F M Moorman ${ }^{2}$, \\ V Christoffels ${ }^{2}$, W M Wiersinga ${ }^{1}$ and $\mathrm{O}$ Bakker $^{1}$
}

${ }^{1}$ Department of Endocrinology and Metabolism and ${ }^{2}$ Department of Anatomy and Embryology, Academic Medical Center, University of Amsterdam, PO Box 22660, 1100DD, Amsterdam, The Netherlands

(Requests for offprints should be addressed to O Bakker at Department of Endocrinology and Metabolism, F5-171, Academic Medical Center, Meibergdreef 9, 1105 AZ Amsterdam, The Netherlands; Email: o.bakker@amc.uva.nl)

\begin{abstract}
Nuclear thyroid hormone $\left(\mathrm{T}_{3}\right)$ receptors (TR) play a critical role in mediating the effects of $\mathrm{T}_{3}$ on development, differentiation and normal physiology of many organs. The heart is a major target organ of $\mathrm{T}_{3}$, and recent studies in knockout mice demonstrated distinct effects of the different TR isoforms on cardiac function, but the specific actions of TR isoforms and their specific localization in the heart remain unclear. We therefore studied the expression of TR $\alpha 1, T R \alpha 2$ and TR $\beta 1$ isoforms in the mouse heart at different stages of development, using monoclonal antibodies against TR $\alpha 1, \operatorname{TR} \alpha 2$ and TR $\beta 1$. In order to identify distinct components of the embryonic heart, in situ hybridization for cardiac-specific markers was used with the expression pattern of sarcoplasmic reticulum calcium-ATPase $2 \mathrm{a}$ as a marker of myocardial structures, while the pattern of expression of connexin 40 was used to indicate the developing chamber myocardium and peripheral ventricular conduction system. Here we show that in the ventricles of the adult heart the TR $\beta 1$ isoform is confined to the cells that form the peripheral ventricular
\end{abstract}

conduction system. TR $\alpha 1$, on the other hand, is present in working myocardium as well as in the peripheral ventricular conduction system. In the atria and in the proximal conduction system (sinoatrial node, atrioventricular node), TR $\alpha 1$ and TR $\beta 1$ isoforms are coexpressed. We also found the heterogeneous expression of the TR $\alpha 1, T R \alpha 2$ and TR $\beta 1$ isoforms in the developing mouse heart, which, in the case of the TR $\beta 1$ isoform, gradually revealed a dynamic expression pattern. It was present in all cardiomyocytes at the early stages of cardiogenesis, but from embryonic day 11.5 and into adulthood, TR $\beta 1$ demonstrated a gradual confinement to the peripheral ventricular conduction system (PVCS), suggesting a specific role of this isoform in the formation of PVCS. Detailed knowledge of the distribution of TR $\alpha 1$ and TR $\beta 1$ in the heart is of importance for understanding not only their mechanism of action in the heart but also the design and (clinical) use of TR isoform-specific agonists and antagonists.

Journal of Endocrinology (2006) 189, 231-245

\section{Introduction}

Tri-iodothyronine $\left(\mathrm{T}_{3}\right)$ affects cardiac function mainly by exerting a direct effect on cardiac cells through binding to thyroid hormone receptors (TR), thus regulating several functionally important proteins responsible for myocardial excitation and contraction (Gloss et al. 2001, Klein \& Ojamaa 2001, Mansen et al. 2001, Dillmann 2002). At present, at least five different TR isoforms $(\alpha 1, \alpha 2, \beta 1, \beta 2$ and $\beta 3$ ) are known (O'Shea \& Williams 2002, Flamant \& Samarut 2003). Although heart has been termed a TR $\alpha 1$ tissue, recent work on TR isoform-specific knockout mice has indicated that both TR isoforms $\alpha 1$ and $\beta 1$ play their part and have distinct effects (Weiss et al. 1998, 2002, Wikstrom et al. 1998, Johansson et al. 1999). Whereas TR $\alpha 1$-deficient mice have bradycardia; prolonged PQ, QRS and $\mathrm{Q}-\mathrm{T}_{\text {end }}$ intervals in the electrocardiogram; and preserved response to stimulation with $\mathrm{T}_{3}, \mathrm{TR} \beta$ deficient mice show tachycardia, shortened $Q-T_{\text {end }}$ interval and lack of response to $\mathrm{T}_{3}$ administration (Weiss et al. 1998, 2002, Wikstrom et al. 1998, Johansson et al. 1999). Hence, TR $\alpha 1$ appears to be involved in determining basal heart rate and ventricular depolarization, while TR $\beta$ appears to have a major function in mediating $\mathrm{T}_{3}$-induced increase in heart rate. The suggestion that activation of TR $\alpha 1$ or TR $\beta 1$ may have distinct effects also derives from studies on GC-1 (Trost et al. 2000, Baxter et al. 2001). This TR $\beta 1$-selective agonist showed no effect on heart rhythm, but it had a positive inotropic effect, again indicating that the receptor isoforms work in different environments. There are no data, however, relating the different inotropic and chronotropic effects of TR isoforms to their presence in different structural components of the heart. Very little is known about the expression 
patterns of the TR isoforms in adult and embryonic heart. In contrast, it is well known that TRs show spatiotemporal dynamics in expression in other organs (Perez-Castillo et al. 1985, Forrest et al. 1991, Bradley et al. 1994, Gauthier et al. 1999). We have recently shown that the TR isoforms are zonally expressed in rodent liver and will therefore act in only a subset of cells (Zandieh et al. 2002, Zandieh-Doulabi et al. 2003). In the brain, TR $\alpha 1$, TR $\alpha 2$ and TR $\beta 1$ isoforms have also distinct expression patterns (Alkemade et al. 2005). In view of this and the differential effects of the TR isoforms mentioned above, we set out to study by immunohistochemistry the distribution of TR $\alpha 1$ and TR $\beta 1$ in mouse heart in the adult and in different stages of the embryonic development.

Within the heart, two types of myocardial components are distinguished functionally: the conduction system (CS) and the working (atrial and ventricular) myocardium. The adult CS consists of separate components. The pacemaking sinoatrial (SAN) and atrioventricular (AVN) nodes are slow-conducting myocardial regions, whereas the atrioventricular bundle (AVB or bundle of His), the right and left bundle branches, and the peripheral ventricular conduction system (PVCS) are fast-conducting pathways. These components vary in their morphologic characteristics and in their molecular phenotype. This is exemplified by the expression pattern of the gap-junction proteins connexin $40(\mathrm{Cx} 40)$ and $43(\mathrm{Cx} 43)$ in the mammalian heart. $\mathrm{Cx} 43$ is expressed throughout the working myocardium and PVCS, but not in the SAN, AVN and atrioventricular bundle, whereas $\mathrm{Cx} 40$ is mainly expressed in the atrial working myocardium, atrioventricular bundle, bundle branches and peripheral ventricular conduction system (PVCS) (Moorman et al. 1998). Therefore, both $\mathrm{Cx} 40$ and $\mathrm{Cx} 43$ can be used as negative markers of the SAN, whereas $\mathrm{Cx} 40$ can be used as a positive marker for the AVB and PVCS. Since SERCA2a is less expressed in the PVCS of embryonic and fetal heart than in the working, compact myocardium, it has also been used to distinguish these two components of the heart (Moorman et al. 1995, 1998).

Here we show that both TR $\alpha 1$ and TR $\beta 1$ are expressed in the myocardium at embryonic day $9 \cdot 5$, but during the later cardiogenesis and in the adult, TR $\beta 1$ expression becomes confined to the atria and the ventricular subendocardial cells that constitute the PVCS. TR $\alpha 1$ is expressed in the atria and all cardiomyocytes of the working myocardium and ventricular conduction system. Furthermore, both TR $\alpha 1$ and TR $\beta 1$ are present in the SAN, AVN and AVB.

\section{Materials and Methods}

\section{Animals}

Mouse embryos from different ages (embryonic days $9 \cdot 5$, $11 \cdot 5,13 \cdot 5,15 \cdot 5$ and $17 \cdot 5)$ or adult mice were killed, and their hearts were collected after removing the thoracic wall. The hearts were processed for immunohistochemistry and in situ hybridization by the same protocol of fixation (overnight $\left(4{ }^{\circ} \mathrm{C}\right)$ in $4 \%$ paraformaldehyde) and embedded in Paraplast Plus (Monoject, Kildare, Ireland). Serial sections of $10 \mu \mathrm{m}$ were cut, mounted on RNasefree slides (Superfrost/Plus; Menzel-Gläser, Braunschweig, Germany) and stored at room temperature. All animal experiments were approved by the local animal welfare committee of the University of Amsterdam.

The liver and heart of the TR $\beta$ knockout mice used in control experiments were the kind gift of Prof B Vennstrom, Stockholm, Sweden.

\section{Immunohistochemistry}

Serial sections were incubated with a new set of specific monoclonal antibodies against TR $\beta 1$ (clone 152), TR $\alpha 1$ and TR $\alpha 2$ (Zandieh et al. 2002, Zandieh-Doulabi et al. 2003). The specificity of the TR $\beta 1$ monoclonal 152 is indicated in Fig. 1. Antibody binding was detected by a goat antimouse secondary antibody, conjugated to alkaline phosphatase, which was visualized by NBT/BCIP (Roche) as a substrate of the alkaline phosphatase. Paraplastembedded embryonic hearts were cut into 10- $\mu$ m-thick sections and pasted on Superfrost/Plus slides (MenzelGläser). Sections were deparaffinized before immunostaining, placed in PBS ( $\mathrm{pH} \mathrm{7.4)}$ and boiled for $2 \mathrm{~min}$ in sodium citrate buffer $(\mathrm{pH}$ 6) to retrieve the antigenic epitope. After cooling to room temperature, the sections were washed in PBS and placed in a blocking solution TENG-T $(0 \cdot 01 \mathrm{M}$ Tris, EDTA, $\mathrm{NaCl}$, gelatin and Tween-20) for $60 \mathrm{~min}$. The first antibodies were diluted in PBS ( $\mathrm{pH} \mathrm{7.4)}$ and incubated first for $1 \mathrm{~h}$ at room temperature and then overnight at $4{ }^{\circ} \mathrm{C}$. The sections were washed with PBS ( $\mathrm{pH} \mathrm{7.4)}$ ) for $10 \mathrm{~min}$, and then incubated with the second antibody (conjugated with alkaline phosphatase) diluted in PBS ( $\mathrm{pH} 7 \cdot 4$ ). After a washing period of $10 \mathrm{~min}$ in PBS, the sections were placed in alkaline phosphatase buffer $(50 \mathrm{mM} \mathrm{MgCl}, 100 \mathrm{mM}$ $\mathrm{NaCl}$ and $100 \mathrm{mM}$ Tris ( $\mathrm{pH} 9 \cdot 2)$ ) for $10 \mathrm{~min}$. The substrate NBT/BCIP (Roche) and 0.1 M levamisole (Sigma) (inhibitor) were diluted respectively 1:50 and $1: 100$ in alkaline phosphatase buffer and added to the sections for 30-90 min in the dark. The sections were washed in PBS and then processed in xylene. The sections were enclosed with Entellan (Merck) (Zandieh et al. 2002, Zandieh-Doulabi et al. 2003).

\section{$R N A$ probes and probe specification}

Poly-A RNA was isolated from mouse liver samples with MagnaPure (Roche) according to the manufacturer's protocol. Thereafter, cDNA was synthesized with the First Strand Synthesis cDNA kit with random primers (Roche). To amplify specific fragments of TRs with 

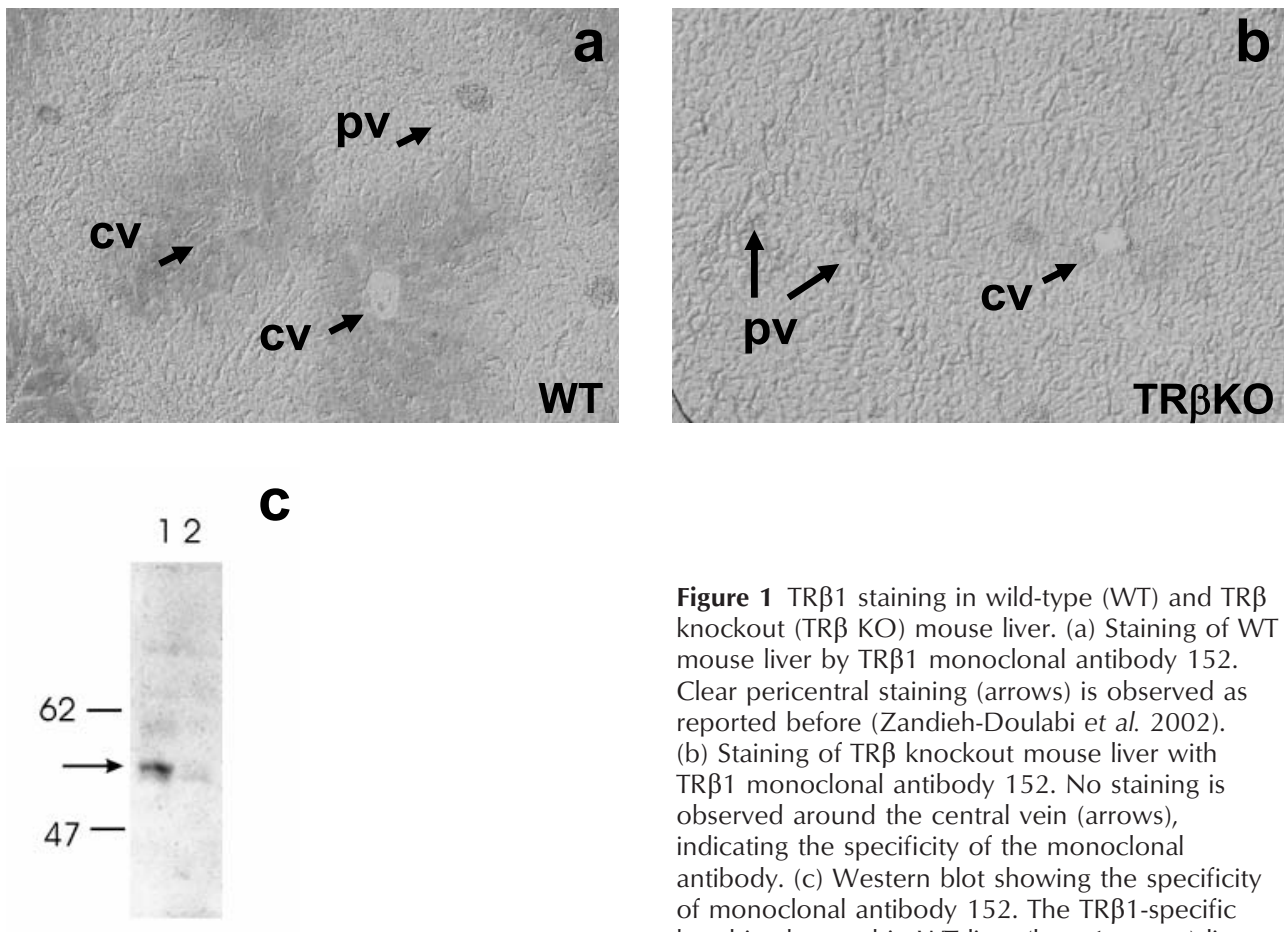

Figure 1 TR $\beta 1$ staining in wild-type (WT) and TR $\beta$ knockout (TR $\beta$ KO) mouse liver. (a) Staining of WT mouse liver by TR $\beta 1$ monoclonal antibody 152 . Clear pericentral staining (arrows) is observed as reported before (Zandieh-Doulabi et al. 2002). (b) Staining of TR $\beta$ knockout mouse liver with TRß1 monoclonal antibody 152. No staining is observed around the central vein (arrows), indicating the specificity of the monoclonal antibody. (c) Western blot showing the specificity of monoclonal antibody 152 . The TR $\beta 1$-specific band is observed in WT liver (lane 1, arrow) liver, but not in TR $\beta$ knockout liver (lane 2). CV, central vein; $p v$, portal vein. Magnification $\times 100$.

attached $\mathrm{T} 7$ or $\mathrm{T}_{3}$ promoters, we performed PCR reactions with the following primers:

- TR $\alpha 1$ (forward, 5'-GAAATTAACCCTCACTAA AGGAAGGCCCAAGCTGCTGATGAAG-3'; reverse, 5'-GTAATACGACTCACTATAGGGCGC TGAGGCTTTAGACTTCCTGATC-3')

- TR $\beta 1$ (forward, 5'-GAAATTAACCCTCACTAA AGGAATGGGCGAGCTCTATATTCCA-3'; reverse 5'-GTAATACGACTCACTATAGGGCACA GGTGATGCAGCGATAGT-3').

The amplified PCR products were used as templates for the synthesis of single-stained, digoxigenin (DIG)-labeled RNA probes, which were made according to the manufacturer's specifications (Roche) and were not subjected to alkaline hydrolysis, because this treatment had no or few adverse effects on the sensitivity of hybridization. Sense probes have been synthesized for a negative control staining with $\mathrm{T}_{3}$-RNA polymerase. The probe labeling and the hybridization conditions were as detailed elsewhere (Moorman et al. 2001). Sequence-specific probes against $\mathrm{Cx} 40$ and $\mathrm{Cx} 43$ have been described previously (Delorme et al. 1995, 1997, Moorman et al. 2001). Complementary RNA probes against bMHC and SERCA2a were used, as detailed elsewhere (Moorman et al. 2001).

\section{Nonradioactive in situ hybridization}

The pretreatment of the sections consisted only of proteolytic digestion for $14 \mathrm{~min}$ at $37^{\circ} \mathrm{C}$ with $20 \mu \mathrm{g} / \mathrm{ml}$ proteinase $\mathrm{K}$ dissolved in PBS, followed by a 5 -min rinse in $0 \cdot 2 \%$ glycine/PBS and two 5 -min rinses in PBS. Sections were then refixed for $20 \mathrm{~min}$ in $4 \%$ formaldehyde $/ 0 \cdot 2 \%$ glutaraldehyde dissolved in PBS to ensure firm attachment of the sections to the microscope slides, and washed twice in PBS for 5 min. Sections were prehybridized in hybridization mix without probe for $1 \mathrm{~h}$ at $70{ }^{\circ} \mathrm{C}$ and then hybridized overnight at $70{ }^{\circ} \mathrm{C}$. The hybridization mix comprises $50 \%$ formamide, $5 \times$ SSC, $1 \%$ block solution (Roche), $5 \mathrm{mM}$ EDTA, 0.1\% Tween-20, 0.1\% Chaps (Sigma), $\quad 0 \cdot 1 \mathrm{mg} / \mathrm{ml}$ heparin (Becton-Dickinson, Mountain View, CA, USA) and $1 \mathrm{mg} / \mathrm{ml}$ yeast total RNA (Roche). Probe concentration was about $2 \mathrm{ng} / \mu \mathrm{l}$. Approximately $10 \mu \mathrm{l}$ hybridization mix were applied to the sections, and no cover slips were used. After hybridization, sections were rinsed in $2 \times \mathrm{SSC}(\mathrm{pH} 4 \cdot 5)$, washed three times for $30 \mathrm{~min}$ at $65{ }^{\circ} \mathrm{C}$ in $50 \%$ formamide/ $2 \times \operatorname{SSC}(\mathrm{pH} 45)$, followed by three 5 -min washes in PBST. Probe bound to the section was immunologically detected by sheep antidigoxigenin Fab fragment covalently coupled to alkaline phosphatase and NBT/ $\mathrm{BCIP}$ as chromogenic substrate, essentially according to 
the manufacturer's protocol (Roche). Sections were washed with double-distilled water, dehydrated in a graded ethanol series and xylene, and embedded in Entellan (Moorman et al. 2001).

\section{Photo imaging}

Images of sections were taken with a digital Olympus DP12 camera coupled to a Zeiss Axiophoto microscope, equipped with differential interference contrast (DIC) optics. A flat-field correction was applied to all images with a user-written macro in PMIS 4.1 (www.gkrcc.com).

\section{Nonradioactive in situ hybridization}

The pretreatment of the sections consisted only of proteolytic digestion for $5-15 \mathrm{~min}$ at $37^{\circ} \mathrm{C}$ with $20 \mu \mathrm{g} / \mathrm{ml}$ proteinase $\mathrm{K}$ dissolved in PBS, followed by a 5-min rinse in $0 \cdot 2 \%$ glycine/PBS and two 5-min rinses in PBS. Sections were then refixed for $20 \mathrm{~min}$ in $4 \%$ formaldehyde $/ 0 \cdot 2 \%$ glutaraldehyde dissolved in PBS to ensure firm attachment of the sections to the microscope slides, and washed twice in PBS for $5 \mathrm{~min}$. Sections were prehybridized in hybridization mix without probe for $1 \mathrm{~h}$ at $70{ }^{\circ} \mathrm{C}$ and then hybridized overnight at $70{ }^{\circ} \mathrm{C}$. The hybridization mix is composed of $50 \%$ formamide, $5 \times$ SSC, $1 \%$ block solution (Roche), $5 \mathrm{mM}$ EDTA, $0 \cdot 1 \%$ Tween-20, 0.1\% Chaps (Sigma), $0 \cdot 1 \mathrm{mg} / \mathrm{ml}$ heparin (Becton-Dickinson), and $1 \mathrm{mg} / \mathrm{ml}$ yeast total RNA (Roche). Probe concentration was about $1 \mathrm{ng} / \mu \mathrm{l}$. Approximately $6 \mu$ l hybridization mix were applied to the sections, and no cover slips were used. After hybridization, sections were rinsed in $2 \times \mathrm{SSC}(\mathrm{pH} 4.5)$ and washed three times for $30 \mathrm{~min}$ at $65{ }^{\circ} \mathrm{C}$ in $50 \%$ formamide $/ 2 \times \mathrm{SSC}(\mathrm{pH} 4 \cdot 5)$, followed by three 5 -min washes in PBST. Probe bound to the section was immunologically detected by sheep antidigoxigenin Fab fragment covalently coupled to alkaline phosphatase and NBT/BCIP as chromogenic substrate, essentially according to the manufacturer's protocol (Roche). Sections were washed with double-distilled water, dehydrated in a graded ethanol series and xylene, and embedded in Entellan (Moorman et al. 2001).

\section{Results}

Nonradioactive in situ hybridization in the adult heart

To map the cells expressing the TR $\alpha 1$ and $\beta 1$ isoforms in the adult mouse heart, we incubated slices of different areas of mouse hearts with sequence-specific probes against TR $\alpha 1$ or TR $\beta 1$. To identify the cells of the conduction system (SAN, AVN and PVCS) in different areas of the heart, we used in situ hybridization with $\mathrm{Cx} 40$ or $\mathrm{Cx} 43$ on consecutive sections (Fig. $2 \mathrm{a}-\mathrm{c}$ and Fig. $3 \mathrm{a}-\mathrm{c}$ )
(Van Kempen et al. 1996, Moorman et al. 2001). In situ hybridization demonstrated that both TR $\alpha 1$ and TR $\beta 1$ isoforms are expressed in the heart, but that their expression, especially that of TR $\beta 1$, is heterogeneous. Both TR $\alpha 1$ and TR $\beta 1$ are present in the atria, SAN and AVN (Fig. 2). The staining for TR $\beta 1$ was weaker, in agreement with previous studies, showing that in the SAN this isoform is four times less expressed than TR $\alpha 1$. In the ventricles, however, TR $\beta 1$ expression was confined to the trabecular structures that form the PVCS in the mouse (Fig. 2). Evidence for this derives from comparing consecutive ventricular sections stained for TR $\beta 1$ and $\mathrm{Cx} 40$, which showed an identical pattern, suggesting specific expression of TR $\beta 1$ in the PVCS (Fig. 2). TR $\alpha 1$ is also expressed in the entire ventricular myocardium, including the PVCS (Fig. 2). All cardiac structures of nonmyocardial origin (pericardium, endocardium and coronary vessels) revealed expression of both isoforms, in agreement with previous data. The in situ hybridization with sense probes was negative, indicating high specificity of the reaction (Fig. 2).

\section{Immunohistochemistry in the adult heart}

To see whether the mRNA is translated and the proteins are also present, we used monoclonal antibodies against TR $\alpha 1$ or TR $\beta 1$. Monoclonal antibody 152 is specific for TR $\beta 1$, as Fig. 1 shows no staining in liver slices of TR $\beta 1$ knockout mice, and the TR $\beta 1$-specific band is not detected in whole-cell liver extracts of these mice. The immunohistochemistry with TR isoform-specific monoclonal antibodies confirmed that both studied isoforms are present in the heart, but have different expression patterns. TR $\alpha 1$ and TR $\beta 1$ were detected in atria, SAN, AVN and ventricle (Fig. 3). As with the mRNA level, TR $\beta 1$ showed a heterogeneous pattern of expression in the ventricles and was highly restricted to the cells of PVCS (Fig. 3). Staining was both nuclear and cytoplasmic, as reported before (Falcone et al. 1992, Zandieh et al. 2002). Valves did not stain and thus gave an additional indication of the specificity of the reaction with the antisera (data not shown). For further verification of the expression profiles, we stained hearts from TR $\beta$ knockout mice, where we did find staining of the PVCS structures for $\mathrm{Cx} 40$ and TR $\alpha 1$, but the TR $\beta 1$ antiserum, as expected, did not stain (Fig. 3, right panel) these structures.

\section{Ontogeny}

Immunohistochemistry with the TR isoform-specific monoclonal antibodies demonstrated that all TR $\alpha 1$, TR $\alpha 2$ and TR $\beta 1$ isoforms are present in the myocardium from embryonic day (E) 9.5 onward. Staining was both nuclear and cytoplasmic. The cardiac cushions did not stain, indicating the specificity of the reaction. The epicardium and the endocardium also showed no staining 

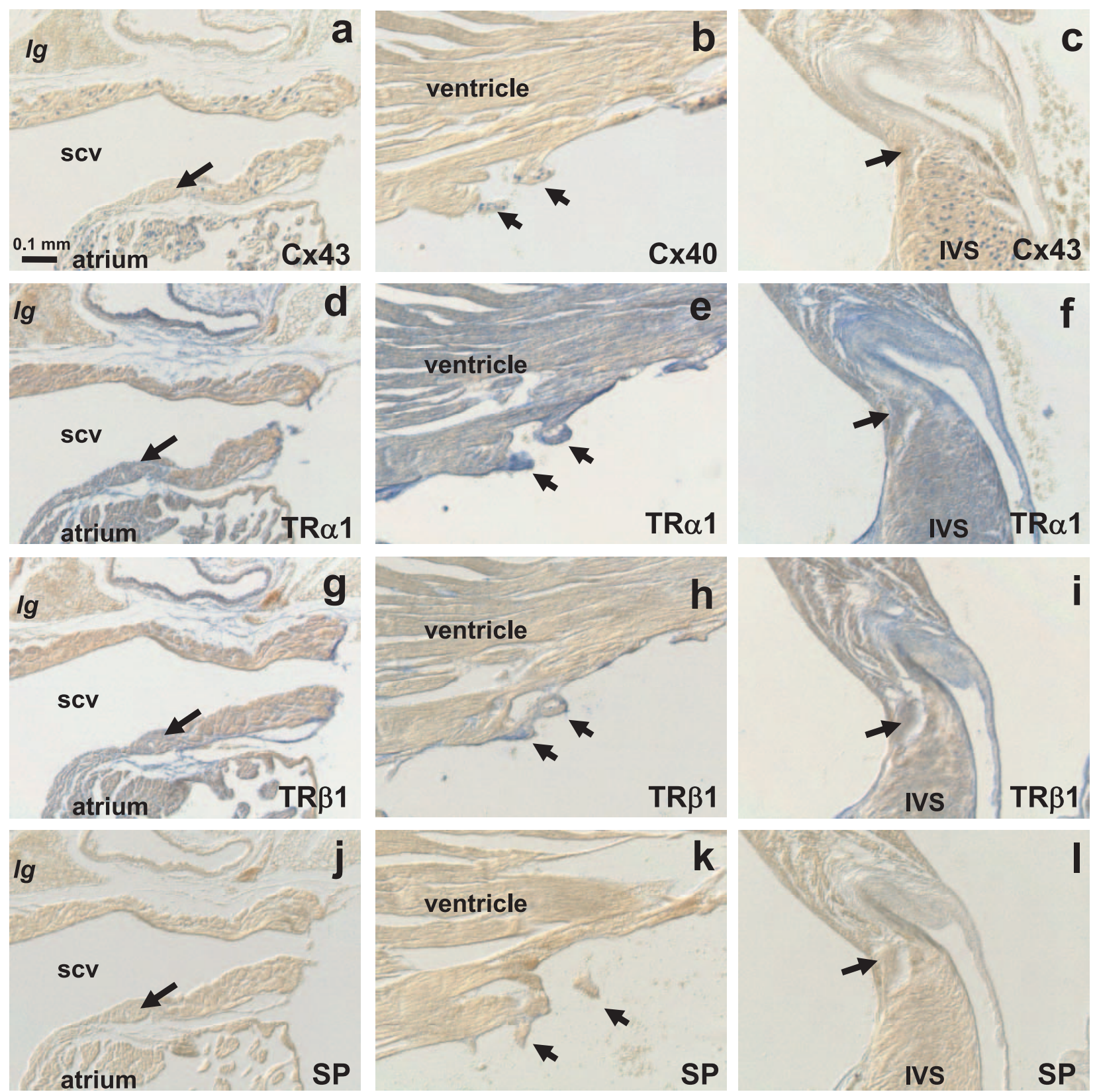

Figure 2 Localisation of TR $\alpha 1$ and TR $\beta 1$ mRNA in the adult mouse heart. Sinoatrial node (SAN) and atrium (a, d, g): in situ hybridisation with antisense probes demonstrates TR $\alpha 1$ and TR $\beta 1$ in consecutive sections and the presence of their mRNAs in the SAN and the atrial myocardium ( $\mathrm{d}$ and g). The SAN is identified by the absence of connexin 43 staining (a). The SAN artery (arrow) is used as an additional morphologic marker of the SAN on the consecutive sections. As a control we hybridised a consecutive section with a TR 1 sense probe (SP; j). Peripheral ventricular conduction system (PVCS; b, e, h): in situ hybridization for connexion 40 (Cx40) identifies the cells that form the subendocardial PVCS (panel b). (e) shows the presence of the TR 1 mRNA in both PVCS (arrows) and working myocardium. (h) shows the presence of the TR $\beta 1$ mRNA only in cells that make up the PVCS (arrows). As a control we hybridized a consecutive section with a TR $\alpha 1$ sense probe (SP; $)$ ). Atrioventricular node (AVN; c, f, i): in situ hybridization with antisense probes detects TR 1 and TR $\beta 1$ on consecutive sections and shows mRNAs present in the AVN ( $f$ and $i)$. The AVN (arrow) is identified by the absence of connexin 43 staining (c). TR 1 mRNA is also expressed in the interventricular septum (IVS; f). As a control we hybridized a consecutive section with a $\mathrm{TR} \alpha 1$ sense probe $(\mathrm{SP} ; \mathrm{I})$. All panels were photographed at the same microscope settings; bar $=0.1 \mathrm{~mm}$. Ig, lung; scv, superior caval vein.

and were used as internal negative controls. The results are described per isoform and the figures per developmental stage.
Again, in order to identify the distinct cardiac components, we performed in situ hybridization staining for Cx40 and SERCA2a (Moorman et al. 1995, 1998, 

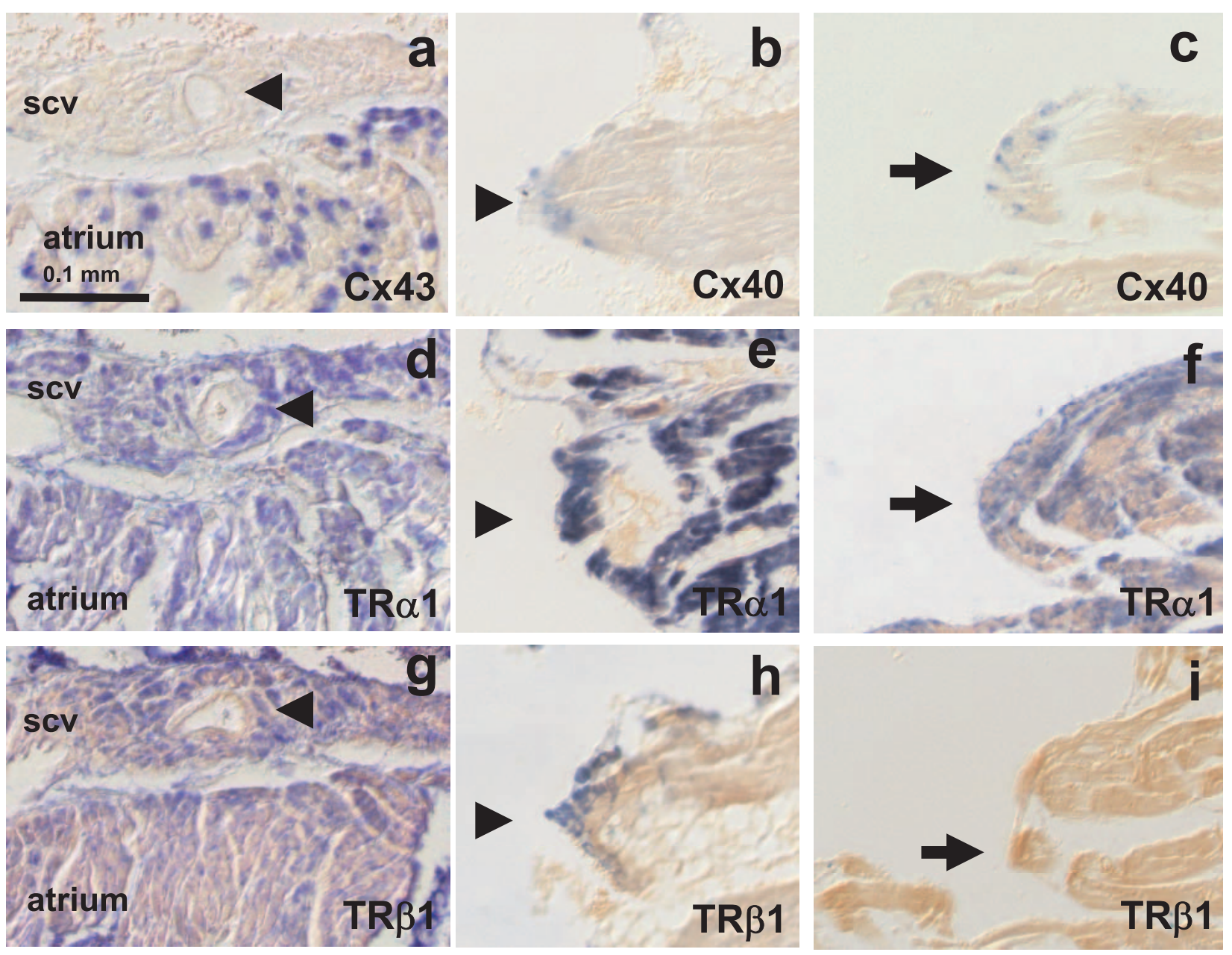

Figure 3 Localisation of TR $\alpha 1$ and TR $\beta 1$ protein in the adult mouse heart. Sinoatrial node (SAN) and atrium (a, d, g): immunohistochemistry with monoclonal antibodies against TR $\alpha 1$ and TR $\beta 1$ in consecutive sections illustrates their presence in the SAN and atrial myocardium ( $\mathrm{d}$ and g). The SAN is identified by the absence of connexin 43 staining (a). The SAN artery (arrowhead) is used as an additional morphologic marker of the SAN on the consecutive sections. Peripheral ventricular conduction system (PVCS; b, e, h): in situ hybridization for connexin 40 (Cx40) identifies cells that form the subendocardial PVCS (b). (e) shows TR 1 immunostaining in both PVCS (arrowhead) and working myocardium. (h) shows TR $\beta 1$ immunostaining only in cells that make up the PVCS. Control staining of a TR $\beta$ knockout mouse heart (i) clearly shows absence of the TR $\beta 1$ signal in the cells that form the PVCS (as identified by a Cx40 staining, c). TR $\alpha 1$ staining in the TR $\beta$ KO shows the same pattern as the wt mouse (compare e and f). All panels were photographed at the same microscope settings; bar $=0.1 \mathrm{~mm}$. SCV, superior caval vein.

Christoffels et al. 2000). Cx40 is restricted to the developing chambers at E $9 \cdot 5$, but, later in development, it becomes confined to the atria, atrioventricular bundle (AVB), bundle branches (bb) and peripheral ventricular conduction system. Cx40 is not present in the sinoatrial node (SAN), the atrioventricular node (AVN) and the ventricular working myocardium (Figs 1-9). However, SERCA2a is expressed in all cardiomyocytes. Both immunohistochemistry and in situ hybridization for SERCA2a show stronger staining in the atria than in the ventricles. Moreover, in the ventricles, the compact myocardium is more stained than the PVCS (Figs 6 and 8). Therefore, $\mathrm{Cx} 40$ is used as a negative marker of the proximal conduction system (SAN and AVN) and a positive marker of the PVCS; SERCA2a is used as a positive marker of the myocardium.

\section{TRa1}

At E 9.5, TR $\alpha 1$ could already be detected in the entire heart tube. All components of the developing myocardium (inflow tract, developing chambers and outflow tract) at E 9.5 were homogeneously stained (Fig. 4). In all developmental stages TR $\alpha 1$ expression was restricted to the myocardium. Endocardium, epicardium, cardiac cushions and valves were negative (Figs 1-9). 


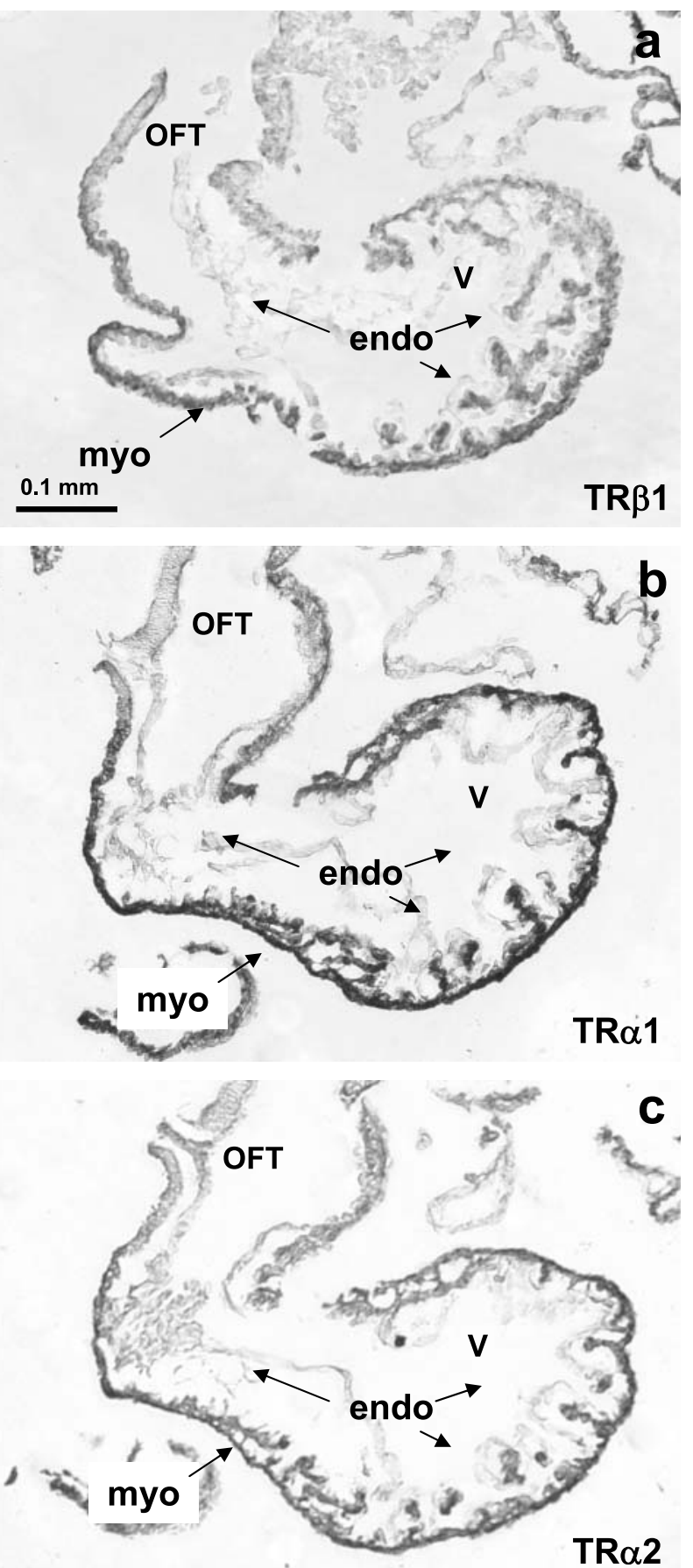

Figure 4 Embryonic age $9 \cdot 5$ days. Consecutive sections $(10 \mu \mathrm{m})$ stained with monoclonal antibodies against TR $\beta 1$ (a), TR $\alpha 1$ (b) and TR $\alpha 2$ (c). OFT, outflow tract; myo, myocardium; endo, endocardium; $\mathrm{V}$, ventricle. Bar $=100 \mu \mathrm{m}$.

Further immunohistochemical study showed that TR $\alpha 1$ is expressed in all cardiomyocytes at all developmental stages studied, including working myocardium and the conduction system (SAN, AVN, AVB, bb and PVCS) (Figs 1-9). Furthermore, TR $\alpha 1$ expression was higher in the atria than in the ventricles in all developmental stages.

\section{TRa2}

At E 9.5, TR $\alpha 2$ could also be detected in all components of the developing myocardium (Fig. 4). Later, TR $\alpha 2$ remained expressed throughout the entire myocardium at all developmental stages, the atria showing stronger expression than the ventricles, as with TR $\alpha 1$ (Figs 6-8). Both the working myocardium and conduction system (SAN, AVN, AVB, bb and PVCS) revealed expression of TR $\alpha 2$ too (Figs 6-8).

\section{$\operatorname{TR} \beta 1$}

At E 9.5, the TR $\beta 1$ isoform showed a similar homogeneous pattern of expression to the other studied isoforms (Fig. 4). The expression of TR $\beta 1$ at E 11.5 was also similar to the other studied isoforms, showing higher expression in the atria than in the ventricles (Fig. 5).

From E 13.5 onward, TR $\beta 1$ showed a distinct pattern of expression, appearing mainly in the SAN, atria and developing PVCS (Fig. 6). The latter can be seen by comparing the expression of TR $\beta 1$ in the ventricles with that of $\mathrm{Cx} 40$, which is higher in the fast-conducting, trabecular structures than in the compact working myocardium (Fig. 6). The trabecular structures will contribute to the PVCS.

At E $13 \cdot 5$, the precise localization of the AVN cannot be assessed, as the fibrous insulation of the atrial and ventricular chambers is not complete and the atrioventricular canal (AVC) is still a distinct anatomic and functional entity. However, Cx40 allows identification of the developing left and right bundle branches along the left and right aspects of the ventricular septum (Figs 6 and 8). In summary, TR $\beta 1$ is present in the atria and all components of the proximal conduction system (SAN, AVC and AVB), showing difference with the expression of $\mathrm{Cx} 40$, which is expressed in the atria, but not in the nodes. Interestingly, the expression pattern of TR $\beta 1$ in the ventricles follows that of $\mathrm{Cx} 40$.

At E $15 \cdot 5$, the ventricular conduction system is entirely recognizable morphologically, although the process of maturation continues. At this stage, TR $\beta 1$ expression remained predominant in the PVCS, represented by subendocardial trabecular structures and distal bundle branches, following the pattern of $\mathrm{Cx} 40$ expression (Fig. 7).

At $\mathrm{E} 17 \cdot 5$, the differences in the expression patterns of the studied isoforms became clearer, and they did not change when compared with the previous embryonic period (Figs 8 and 9). 


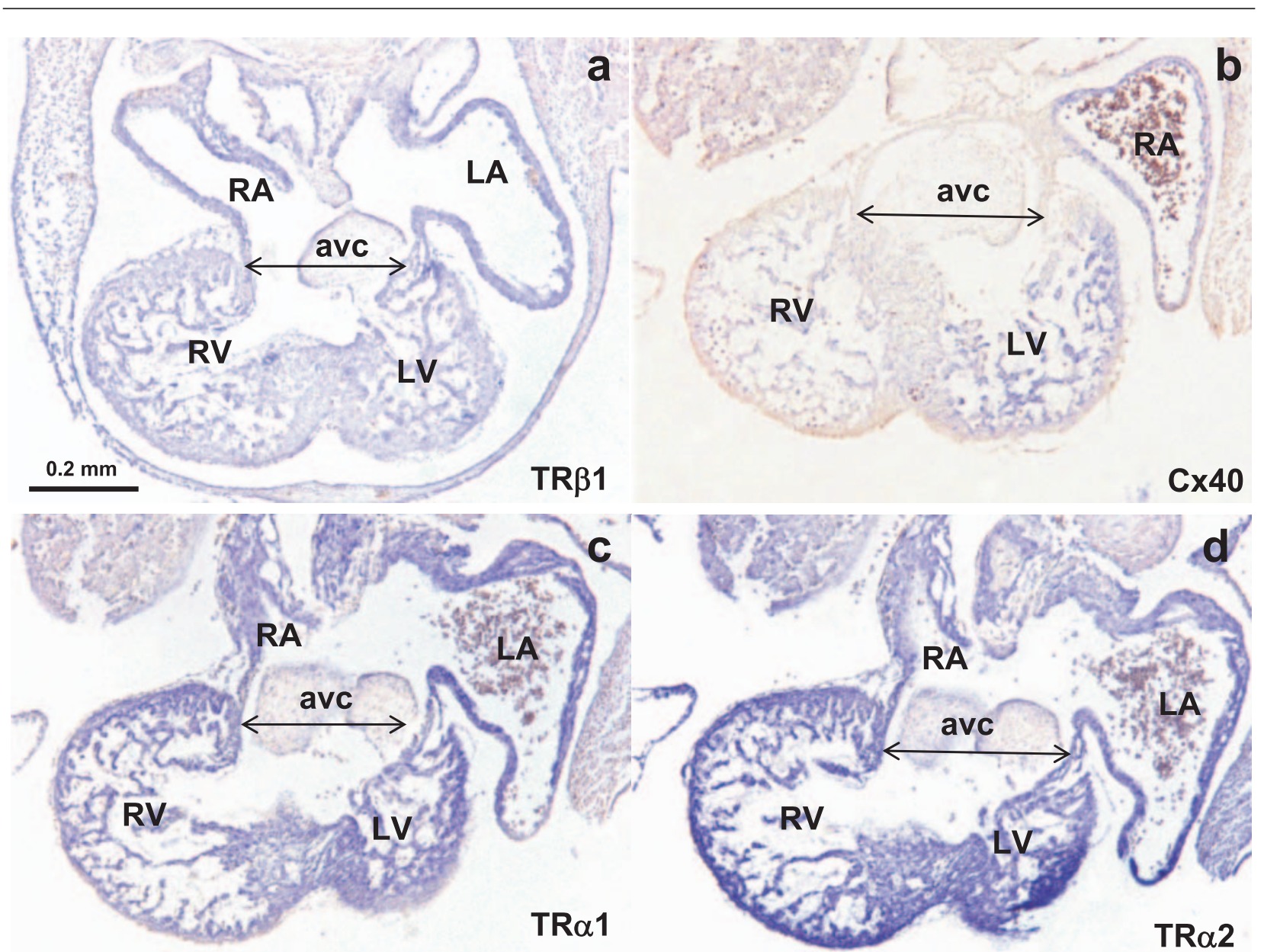

Figure 5 Embryonic age 11.5 days. Consecutive sections $(10 \mu \mathrm{m})$ stained with monoclonal antibodies against TR $\beta 1$ (a), TR 1 (c), TR $\alpha 2$ (d) (immunohistochemistry) and DIG-labeled RNA probe for $\mathrm{Cx} 40$ (b) (in situ hybridization). The atrioventricular canal is indicated by arrow. avc, atrioventricular canal; RA, right atrium; LA, left atrium; RV, right ventricle; LV, left ventricle. Bar $=0 \cdot 2 \mathrm{~mm}$.

\section{Discussion}

Various developmental and morphologic studies have identified the heart as a complex organ composed of functionally and morphologically distinct components (Moorman et al. 1998, Christoffels et al. 2000, Franco \& Icardo 2001). Based on the structural and functional heterogeneity of the heart, we hypothesized that the different thyroid hormone receptor isoforms could be differentially expressed in the cardiac components and that this can partly account for functional differences of the TR isoforms.

Here we show that TR $\beta 1$ expression in the adult is confined to the PVCS, a structure responsible for the fast, simultaneous excitation of the ventricular myocardium. This confined expression pattern is seen at both mRNA and protein level. The stronger immunohistochemical staining agrees with studies showing that, when comparing the embryonal with the adult heart, the total mRNA concentration decreases, whereas the total protein concentration increases almost threefold (van den Hoff \& Moorman 1999). The expression of TR $\alpha 1$ throughout both the ventricular working myocardium and the conduction system confirms previous results (Wikstrom et al. 1998, Dillmann 2002, Weiss et al. 2002). Not only is TR $\alpha 1$ the most abundantly present TR isoform in the heart, but it is also responsible for most cardiac actions of $\mathrm{T}_{3}$ (Wikstrom et al. 1998, Gloss et al. 2001, Dillmann 2002, Weiss et al. 2002).

During the formation of the heart, we found that TR $\alpha 1$, TR $\alpha 2$ and TR $\beta 1$ isoforms are expressed in myocardium from E $9 \cdot 5$ onward. The cardiac expression of all isoforms was confined to the myocardium. The presence of the TR isoforms in early stages of heart development agrees with previous RNA-based studies (Forrest et al. 1991, Bradley et al. 1994, Brent 1994). In line with these observations, TR $\alpha$ knockout embryos display a cardiac phenotype already at E 9.5 (Mai et al. 2004). 

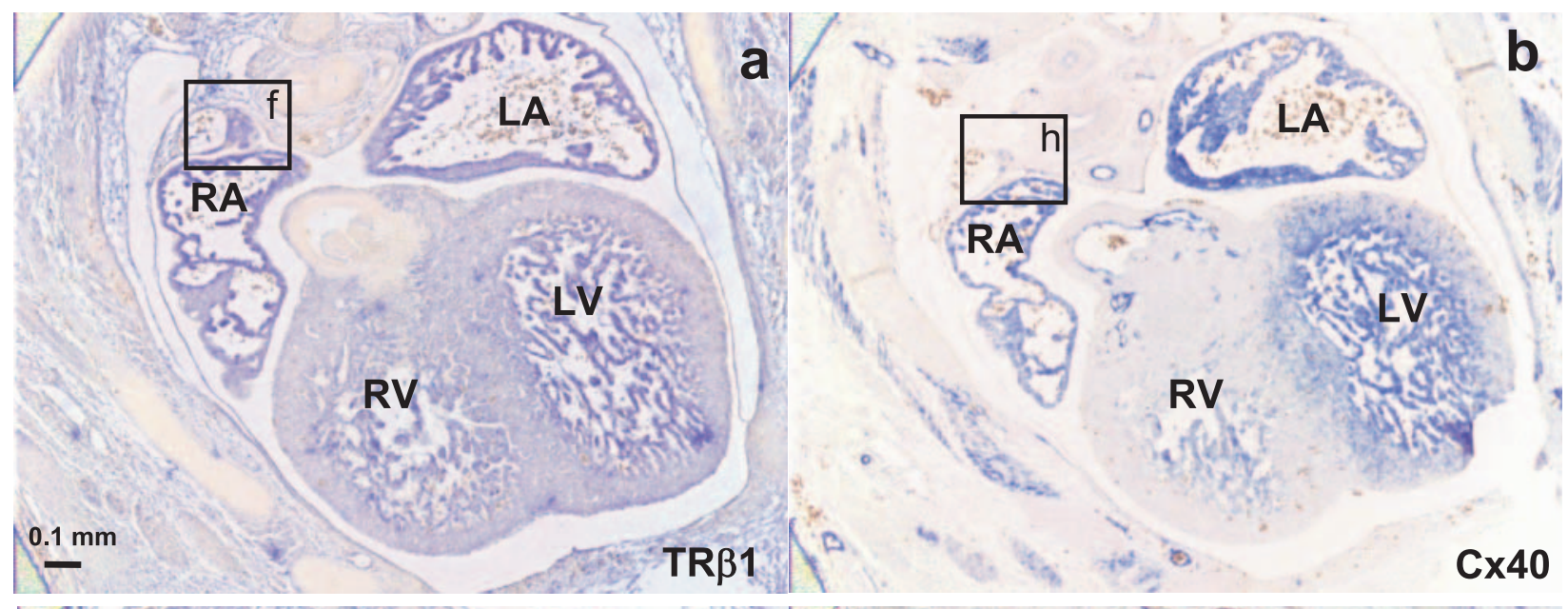

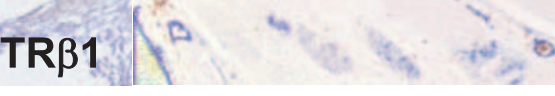

Cx40
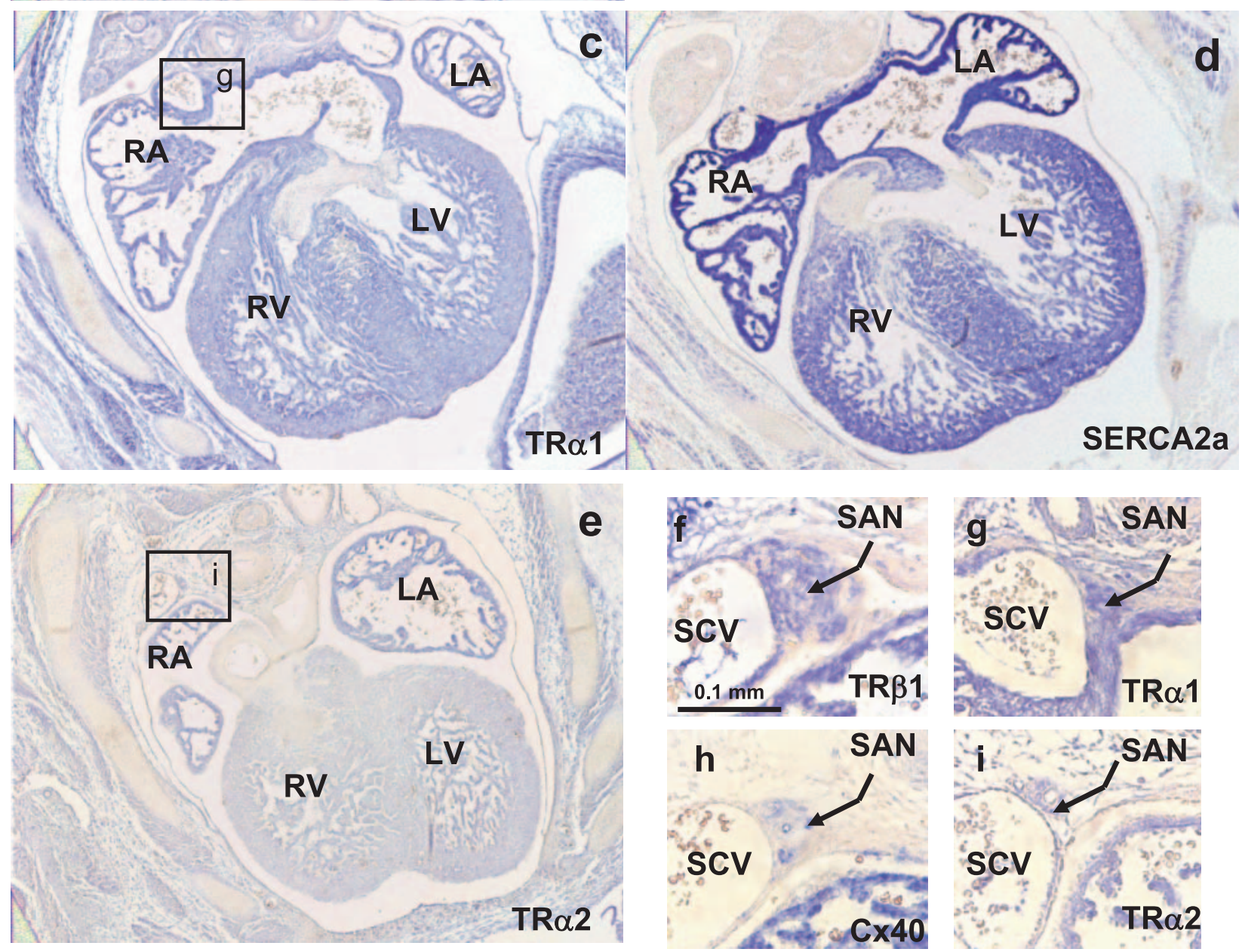

Figure 6 Embryonic age 13.5 days. Consecutive sections $(10 \mu \mathrm{m})$ stained with monoclonal antibodies directed against TR $\beta 1$ (a), TR $\alpha 1$ (c), TR 22 (e) (immunohistochemistry), and DIG-labeled RNA probe for Cx40 (b) and SERCA2a (d) (in situ hybridization; ISH). The arrows on the insets indicate the sinoatrial node (SAN). The comparison of the staining of consecutive slices with TR $\beta 1$ monoclonal antibody and Cx40 ISH indicates the predominant expression of TR $\beta 1$ in the peripheral ventricular subendocardial conduction system (PVCS). It can be seen that all TR isoforms are expressed in the SAN, in contrast to Cx40, which is present in the SAN artery, but not in the myocardium. In the ventricles, however, TR $\beta 1$ has a similar expression pattern to Cx40. RA, right atrium; LA, left atrium; RV, right ventricle; LV, left ventricle; SCV, superior caval vein. Bar $=100 \mu \mathrm{m}$. 

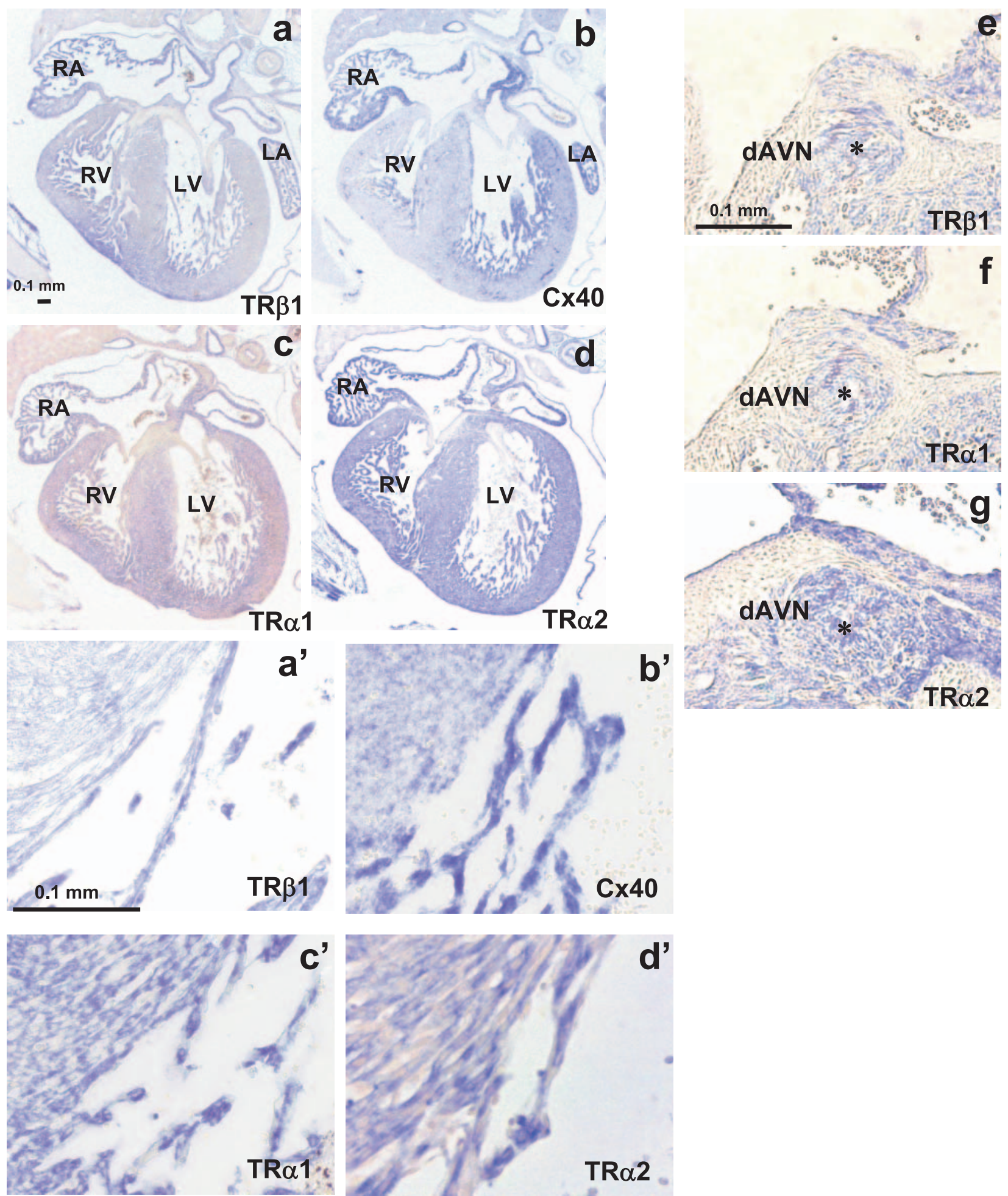

Figure 7 Embryonic age 15.5 days. Consecutive sections $(10 \mu \mathrm{m})$ stained with monoclonal antibodies directed against TR $\beta 1$ (a), TR $\alpha 1$ (c), TRa2 (d) (immunohistochemistry; IHC) and DIG-labeled RNA probe for Cx40 (b) (in situ hybridization). (e-g) indicate the distal atrioventricular node (AVN)/proximal atrioventricular bundle (AVB) (indicated by asterisk). ( $\left.a^{\prime}-d^{\prime}\right)$ show peripheral ventricular conduction system (PVCS). The comparison of the staining of consecutive slices with the TR $\beta 1$ monoclonal antibody and Cx40 IHC indicates the predominant expression of TR $\beta 1$ in the subendocardial conduction system. RA, right atrium; LA, left atrium; RV, right ventricle; LV, left ventricle. Bar=100 $\mu$ m. 

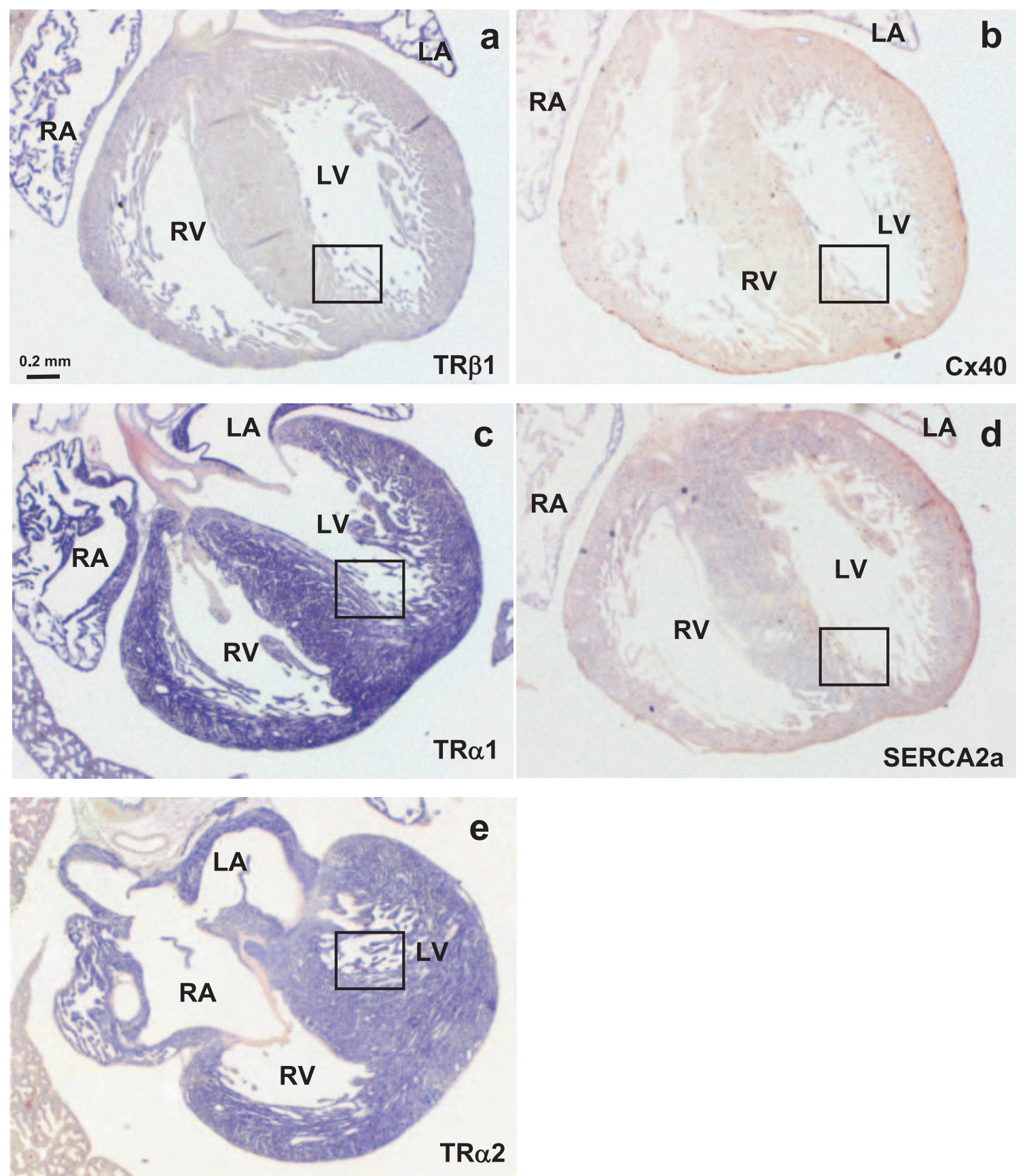

Figure 8 Embryonic age 17.5 days. Consecutive sections $(10 \mu \mathrm{m})$ stained with monoclonal antibodies against TR $\beta 1$ (a), TR $\alpha 1$ (c), TR $\alpha 2$ (e) (immunohistochemistry) and DIG-labeled RNA probe for Cx40 (b) and SERCA2a (d) (in situ hybridization; ISH). The branches indicate the peripheral ventricular conduction system (PVCS) (for a higher magnitude, see Fig. 6). The comparison of the staining of consecutive slices with the TR $\beta 1$ monoclonal antibody and $\mathrm{Cx} 40 \mathrm{ISH}$ indicates the predominant expression of TR $\beta 1$ in the subendocardial conduction system. Lack of expression of SERCA2a in these structures also identifies these structures as PVCS. RA, right atrium; LA, left atrium; $\mathrm{RV}$, right ventricle; $\mathrm{LV}$, left ventricle. Bar $=0.2 \mathrm{~mm}$.

The presence of TRs in the heart and lung before the development of the thyroid gland and secretion of thyroid hormone, which occurs in mice after E 15, suggests that the TRs exert their action in a $\mathrm{T}_{3}$-independent manner or that TRs can be activated by maternal $\mathrm{T}_{3}$. The first hypothesis is supported by the finding that TRs can repress 

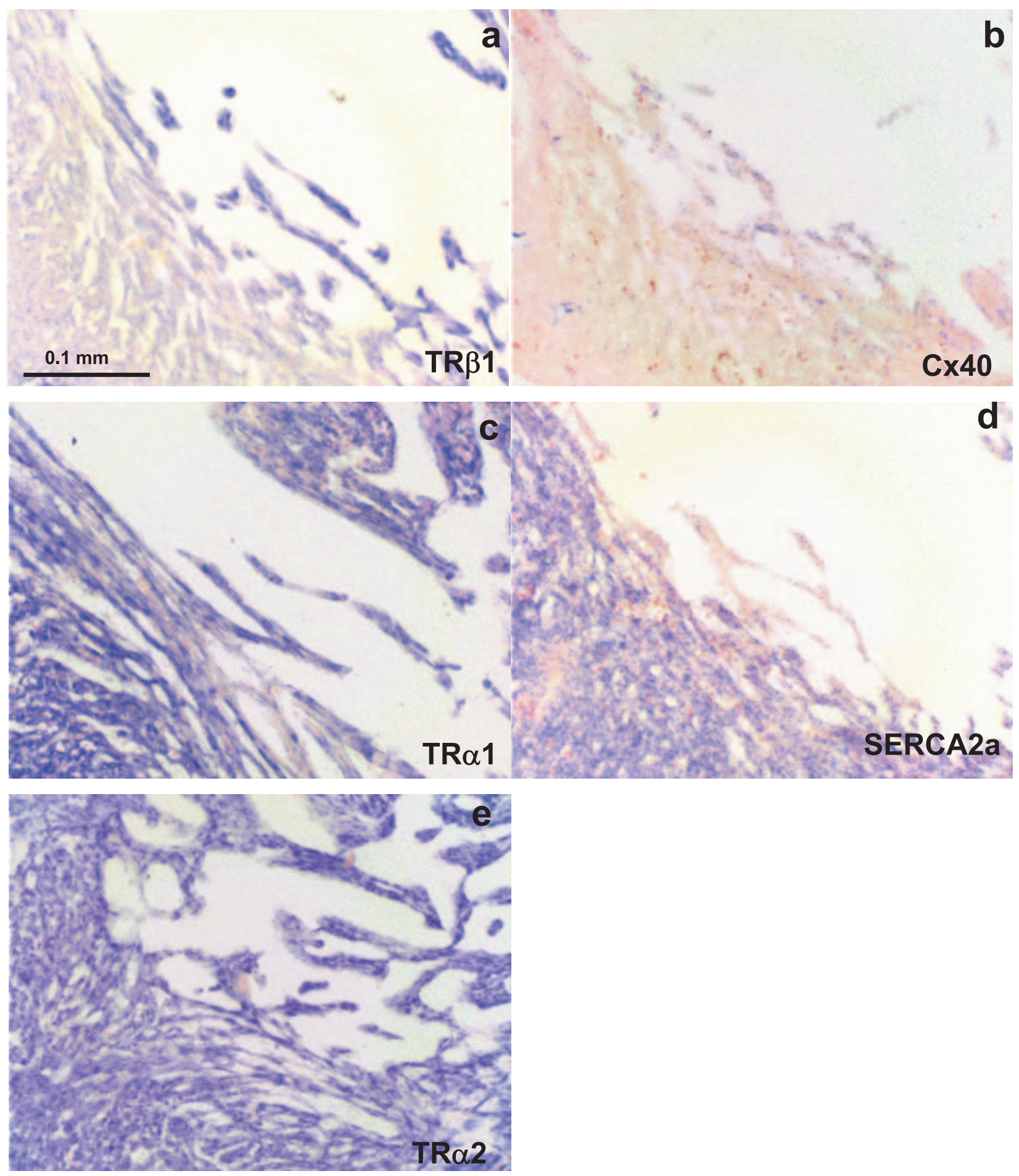

Figure 9 Peripheral ventricular conduction system (PVCS) at embryonic age 17.5 days (from Fig. 8). Only a few cells stained for Cx40 (b) and negative for SERCA2a (d) are identified as PVCS. The staining of a consecutive slice with the TR $\beta 1$ monoclonal antibody (a) shows that the same cells stain with this antibody, indicating the predominant expression of TR $\beta 1$ in the subendocardial conduction system. The figure shows consecutive sections $(10 \mu \mathrm{m})$ stained with monoclonal antibodies against TR $\beta 1$ (a), TR $\alpha 1$ (c), TR $\alpha 2$ (e) (immunohistochemistry) and DIG-labeled RNA probe for Cx40 (b), and SERCA2a (d) (in situ hybridization). Bar=100 $\mu \mathrm{m}$. 
certain genes in the absence of $\mathrm{T}_{3}$ and act as antagonists of retinoid acid receptors (RAR) (Brent et al. 1989, Brand 2003, Clabby et al. 2003). In addition, low levels of $T_{3}$ during pregnancy do not seem to affect prenatal heart development (van Tuyl et al. 2004). However, maternal hypothyroidism seriously affects the postnatal cardiac maturation, even at normal $\mathrm{T}_{3}$ levels (van Tuyl et al. 2004). Although the exact functions of the distinct TRs at this developmental stage still remain unclear, their presence in the heart indicates that they have an important role in the early cardiogenesis and may imply that the thyroid status of the mother during pregnancy affects cardiogenesis.

We found also that each studied isoform has a distinct expression pattern and follows specific dynamics during heart ontogenesis. TR $\alpha 1$ and TR $\alpha 2$ were present in all cardiomyocytes in all studied embryonic stages, being more abundant in the atria than in the ventricles. TR $\beta 1$ was also ubiquitously expressed at E $9 \cdot 5$, but later in development, namely, E $11 \cdot 5$, E 13.5 and E 15.5 , it was progressively confined to the atria, SAN and ventricular trabecular structures that will become the peripheral ventricular conduction system. Our findings could be of great importance for understanding the specific actions of the TR isoforms, because the TR-dependent genes are heterogeneously expressed in distinct cardiac components, and they could be regulated specifically by TR $\alpha 1, T R \beta 1$ or both isoforms (Moorman et al. 1995, 1998, Franco \& Icardo 2001). Moreover, the pleiotropic effect of the mutation in TR $\alpha 1$ is consistent with the wide distribution of TR $\alpha 1$, whereas the more limited alterations generated by the ablation of the TR $\beta 1$ gene agree with the more restricted pattern of expression observed for TR $\beta 1$ (Gloss et al. 2001).

The most significant effect of TRs in heart development is on the regulation of differential expression of $\alpha$ and $\beta$-myosin heavy-chain isoforms in the rodent heart. In the prenatal period, the $\alpha$-myosin heavy chain becomes confined to the atria, and the $\beta$-myosin heavy chain to the ventricles. After delivery, a peak of $\mathrm{T}_{3}$ secretion leads to upregulation of the $\alpha$-isoform in the ventricles and a concomitant suppression of the $\beta$-isoform. No significant increase of the $\alpha$-isoform in the atria is observed (Klein et al. 1992, Morkin 1993, 2000, Klein \& Ojamaa 2001, Mansen et al. 2001, Dillmann 2002). The differences in response to $\mathrm{T}_{3}$ action between the atria and the ventricles could be related to the higher expression of TR $\alpha 1$ and TR $\beta 1$ isoforms in the atria. Since all TRs show less expression in the ventricles than in the atria, it could be that high hormone levels are needed to stimulate the $\alpha$-myosin heavy chain in the ventricles.

The regional expression of the TRs can also explain why phospholamban and SERCA2a are predominantly TR $\alpha 1$, but not TR $\beta 1$, regulated in vivo (Gloss et al. 2001, Klein \& Ojamaa 2001, Dillmann 2002). Both proteins are highly expressed in the compact myocardium but significantly lower or absent in the trabeculae (Moorman et al. 1995).
Therefore, the fact that $\operatorname{TR} \beta 1$ is present only in these trabecular structures goes a long way to explain the lack of TR $\beta 1$ regulation of phospholamban and SERCA2 in vivo. That this lack of regulation is indeed distribution dependent follows from the fact that TR $\beta 1$ can regulate both these genes in vitro in rat cardiomyocyte cell cultures when they are transfected with TR $\beta 1$ (Moriscot et al. 1997, Gloss et al. 2001).

A novel finding in our experiments was that $T R \beta 1$ is expressed mainly in the ventricular trabeculations after 13.5 E. It is known that these structures differentiate eventually into the peripheral ventricular conduction system (Moorman et al. 1998, Franco \& Icardo 2001). Formation of the PVCS is stimulated by the endocardium-derived paracrine factors, neuregulin-1 (Rentschler et al. 2002) and endothelin (Yanagisawa et al. 1988, Masaki et al. 1991, Gourdie et al. 1998). The idea that the TR $\beta 1$ isoform has a specific role in the PVCS because of its restricted expression is supported by data which show that the effect of endothelin is enhanced in rat cardiomyocyte cells transfected with TR $\beta 1$, resulting in hypertrophy and expression of specific proteins (Liang et al. 2003). The distinct pattern of expression of TR $\beta 1$ could help to clarify the different chronotropic and hypertropic effects of $\mathrm{T}_{3}$ on the heart.

Both TR $\alpha 1$ and TR $\beta 1$ are present in atria and SAN. The abundant presence of TR $\alpha 1$ in the SAN agrees with the data on the role that this isoform plays in regulation of basic heart rate and expression of the guanine-nucleotide regulatory proteins (HCN2 and $\mathrm{HCN} 4)$ responsible for the pacemaking current (Pachucki et al. 1999, Gloss et al. 2001). The presence of TR $\beta 1$ protein in the SAN agrees with previous studies on RNA level (Gloss et al. 2001, Swanson et al. 2003) and suggests a role for TR $\beta 1$ in pacemaking activity too. Support for this role can be found in a recent report that TR $\beta^{\mathrm{PV} / \mathrm{PV}}$ mice, under euthyroid conditions, have decreased heart rate, demonstrating that despite a lower expression of TR $\beta$ than TR $\alpha 1$ in the mouse heart, the homozygous negative PV/PV mutation of TR $\beta 1$ can negatively interfere with TR $\alpha 1$ signaling in this organ (Swanson et al. 2003). Furthermore, our data support the conclusions of Swanson et al. (2003) on the expression and abundance of TR $\alpha 1$, but, on the ventricles, they do not support their conclusion that TR $\beta 1$ is ubiquitously expressed in the heart.

Our results are also consistent with studies on $T_{3}$ antagonists and agonists. For instance, it was not clear why dronedarone, a selective TR $\alpha 1$ antagonist, in contrast to amiodarone (a nonselective TR antagonist), causes ventricular arrhythmia in dogs as a side effect (Van Beeren et al. 1996, 2003, Varro et al. 2001). A possible unique function of TR $\beta 1$ in the ventricular conduction system could provide the explanation. The predominant expression of TR $\alpha 1$ in the myocardium, on the other hand, could be the reason that the selective TR $\beta 1$ agonists GS-1 and KB-141 have little or no effect on cardiac 
function (Trost et al. 2000, Baxter et al. 2001, Grover et al. 2003).

These results are, to our knowledge, the first to show the heterogeneous distribution of TR $\alpha 1$ and $\operatorname{TR} \beta 1$ in the cardiac conduction system and working myocardium. Knowledge of the distribution of these two isoforms, and especially the specific expression of TR $\beta 1$ in PVCS, will be of great importance not only for understanding their functions in the heart but also for the design and (clinical) use of TR isoform-specific agonists and antagonists.

\section{Acknowledgements}

The authors declare that there is no conflict of interest that would prejudice the impartiality of this scientific work.

\section{References}

Alkemade A, Vuijst CL, Unmehopa UA, Bakker O, Vennstrom B, Wiersinga WM, Swaab DF \& Fliers E 2005 Thyroid hormone receptor expression in the human hypothalamus and anterior pituitary. Journal of Clinical Endocrinology and Metabolism 90 904-912.

Baxter JD, Dillmann WH, West BL, Huber R, Furlow JD, Fletterick RJ, Webb P, Apriletti JW \& Scanlan TS 2001 Selective modulation of thyroid hormone receptor action. Journal of Steroid Biochemistry and Molecular Biology 76 31-42.

Bradley DJ, Towle HC \& Young WS III 1994 Alpha and beta thyroid hormone receptor (TR) gene expression during auditory neurogenesis: evidence for TR isoform-specific transcriptional regulation in vivo. PNAS 91 439-443.

Brand T 2003 Heart development: molecular insights into cardiac specification and early morphogenesis. Developmental Biology 258 1-19.

Brent GA 1994 The molecular basis of thyroid hormone action. New England Journal of Medicine 331 847-853.

Brent GA, Dunn MK, Harney JW, Gulick T, Larsen PR \& Moore DD 1989 Thyroid hormone aporeceptor represses T3-inducible promoters and blocks activity of the retinoic acid receptor. New Biology 1 329-336.

Christoffels VM, Habets PE, Franco D, Campione M, de Jong F, Lamers WH, Bao ZZ, Palmer S, Biben C, Harvey RP et al. 2000 Chamber formation and morphogenesis in the developing mammalian heart. Developmental Biology 223 266-278.

Clabby ML, Robison TA, Quigley HF, Wilson DB \& Kelly DP 2003 Retinoid X receptor alpha represses GATA-4-mediated transcription via a retinoid-dependent interaction with the cardiac-enriched repressor FOG-2. Journal of Biological Chemistry 278 5760-5767.

Delorme B, Dahl E, Jarry-Guichard T, Marics I, Briand JP, Willecke K, Gros D \& Theveniau-Ruissy M 1995 Developmental regulation of connexin 40 gene expression in mouse heart correlates with the differentiation of the conduction system. Developmental Dynamics 204 358-371.

Delorme B, Dahl E, Jarry-Guichard T, Briand JP, Willecke K, Gros D \& Theveniau-Ruissy M 1997 Expression pattern of connexin gene products at the early developmental stages of the mouse cardiovascular system. Circulation Research 81 423-437.

Dillmann WH 2002 Cellular action of thyroid hormone on the heart. Thyroid 12 447-452.

Falcone M, Miyamoto T, Fierro-Renoy F, Macchia E \& DeGroot LJ 1992 Antipeptide polyclonal antibodies specifically recognize each human thyroid hormone receptor isoform. Endocrinology $1312419-2429$.
Flamant F \& Samarut J 2003 Thyroid hormone receptors: lessons from knockout and knock-in mutant mice. Trends in Endocrinology and Metabolism 14 85-90.

Forrest D, Hallbook F, Persson H \& Vennstrom B 1991 Distinct functions for thyroid hormone receptors alpha and beta in brain development indicated by differential expression of receptor genes. EMBO Journal 10 269-275.

Franco D \& Icardo JM 2001 Molecular characterization of the ventricular conduction system in the developing mouse heart: topographical correlation in normal and congenitally malformed hearts. Cardiovascular Research 49 417-429.

Gauthier K, Chassande O, Plateroti M, Roux JP, Legrand C, Pain B, Rousset B, Weiss R, Trouillas J \& Samarut J 1999 Different functions for the thyroid hormone receptors TRalpha and TRbeta in the control of thyroid hormone production and post-natal development. EMBO Journal 18 623-631.

Gloss B, Trost S, Bluhm W, Swanson E, Clark R, Winkfein R, Janzen K, Giles W, Chassande O, Samarut J et al. 2001 Cardiac ion channel expression and contractile function in mice with deletion of thyroid hormone receptor alpha or beta. Endocrinology 142 544-550.

Gourdie RG, Wei Y, Kim D, Klatt SC \& Mikawa T 1998 Endothelin-induced conversion of embryonic heart muscle cells into impulse-conducting Purkinje fibers. PNAS 95 6815-6818.

Grover GJ, Mellstrom K, Ye L, Malm J, Li YL, Bladh LG, Sleph PG, Smith MA, George R, Vennstrom B et al. 2003 Selective thyroid hormone receptor-beta activation: a strategy for reduction of weight, cholesterol, and lipoprotein (a) with reduced cardiovascular liability. PNAS 100 10067-10072.

Johansson C, Gothe S, Forrest D, Vennstrom B \& Thoren P 1999 Cardiovascular phenotype and temperature control in mice lacking thyroid hormone receptor-beta or both alpha1 and beta. American Journal of Physiology 276 H2006-H2012.

Klein I \& Ojamaa K 2001 Thyroid hormone and the cardiovascular system. New England Journal of Medicine 344 501-509.

Klein I, Ojamaa K, Samarel AM, Welikson R \& Hong C 1992 Hemodynamic regulation of myosin heavy chain gene expression. Studies in the transplanted rat heart. Journal of Clinical Investigations 89 68-73.

Lazar MA 1993 Thyroid hormone receptors: multiple forms, multiple possibilities. Endocrine Reviews 14 184-193.

Liang F, Webb P, Marimuthu A, Zhang S \& Gardner DG 2003 Triiodothyronine increases brain natriuretic peptide (BNP) gene transcription and amplifies endothelin-dependent BNP gene transcription and hypertrophy in neonatal rat ventricular myocytes. Journal of Biological Chemistry 278 15073-15083.

Mai W, Janier MF, Allioli N, Quignodon L, Chuzel T, Flamant F \& Samarut J 2004 Thyroid hormone receptor alpha is a molecular switch of cardiac function between fetal and postnatal life. PNAS 101 10332-10337.

Mansen A, Yu F, Forrest D, Larsson L \& Vennstrom B 2001 TRs have common and isoform-specific functions in regulation of the cardiac myosin heavy chain genes. Molecular Endocrinology 15 2106-2114.

Masaki T, Kimura S, Yanagisawa M \& Goto K 1991 Molecular and cellular mechanism of endothelin regulation. Implications for vascular function. Circulation 84 1457-1468.

Moorman AF, Vermeulen JL, Koban MU, Schwartz K, Lamers WH \& Boheler KR 1995 Patterns of expression of sarcoplasmic reticulum $\mathrm{Ca}(2+)$-ATPase and phospholamban mRNAs during rat heart development. Circulation Research 76 616-625.

Moorman AF, de Jong F, Denyn MM \& Lamers WH 1998 Development of the cardiac conduction system. Circulation Research 82 629-644.

Moorman AF, Houweling AC, de Boer PA \& Christoffels VM 2001 Sensitive nonradioactive detection of mRNA in tissue sections: novel application of the whole-mount in situ hybridization protocol. Journal of Histochemistry and Cytochemistry 49 1-8. 
Moriscot AS, Sayen MR, Hartong R, Wu P \& Dillmann WH 1997 Transcription of the rat sarcoplasmic reticulum $\mathrm{Ca}^{2+}$ adenosine triphosphatase gene is increased by $3,5,3^{\prime}$-triiodothyronine receptor isoform-specific interactions with the myocyte-specific enhancer factor-2a. Endocrinology 138 26-32.

Morkin E 1993 Regulation of myosin heavy chain genes in the heart. Circulation 87 1451-1460.

Morkin E 2000 Control of cardiac myosin heavy chain gene expression. Microscopic Research Techniques 50 522-531.

O'Shea PJ \& Williams GR 2002 Insight into the physiological actions of thyroid hormone receptors from genetically modified mice. Journal of Endocrinology 175 553-570.

Pachucki J, Burmeister LA \& Larsen PR 1999 Thyroid hormone regulates hyperpolarization-activated cyclic nucleotide-gated channel (HCN2) mRNA in the rat heart. Circulation Research 85 498-503.

Perez-Castillo A, Bernal J, Ferreiro B \& Pans T 1985 The early ontogenesis of thyroid hormone receptor in the rat fetus. Endocrinology 117 2457-2461.

Rentschler S, Zander J, Meyers K, France D, Levine R, Porter G, Rivkees SA, Morley GE \& Fishman GI 2002 Neuregulin-1 promotes formation of the murine cardiac conduction system. PNAS 99 10464-10469.

Swanson EA, Gloss B, Belke DD, Kaneshige M, Cheng SY \& Dillmann WH 2003 Cardiac expression and function of thyroid hormone receptor beta and its PV mutant. Endocrinology 144 4820-4825.

Trost SU, Swanson E, Gloss B, Wang-Iverson DB, Zhang H, Volodarsky T, Grover GJ, Baxter JD, Chiellini G, Scanlan TS et al. 2000 The thyroid hormone receptor-beta-selective agonist GC-1 differentially affects plasma lipids and cardiac activity. Endocrinology 141 3057-3064.

Van Beeren HC, Bakker O \& Wiersinga WM 1996 Structurefunction relationship of the inhibition of the $3,5,3^{\prime}$ triiodothyronine binding to the alpha1- and beta1-thyroid hormone receptor by amiodarone analogs. Endocrinology $1372807-2814$.

Van Beeren HC, Jong WM, Kaptein E, Visser TJ, Bakker O \& Wiersinga WM 2003 Dronerarone acts as a selective inhibitor of 3,5,3'-triiodothyronine binding to thyroid hormone receptoralpha1: in vitro and in vivo evidence. Endocrinology 144 552-558.

van den Hoff MJ \& Moorman AF 1999 Measure is treasure. Cardiovascular Research 43 288-290.

Van Kempen MJ, Vermeulen JL, Moorman AF, Gros D, Paul DL \& Lamers WH 1996 Developmental changes of connexin40 and connexin 43 mRNA distribution patterns in the rat heart. Cardiovascular Research 32 886-900. van Tuyl M, Blommaart PE, de Boer PA, Wert SE, Ruijter JM, Islam S, Schnitzer J, Ellison AR, Tibboel D, Moorman AF et al. 2004 Prenatal exposure to thyroid hormone is necessary for normal postnatal development of murine heart and lungs. Developmental Biology 272 104-117.

Varro A, Takacs J, Nemeth M, Hala O, Virag L, Iost N, Balati B, Agoston M, Vereckei A, Pastor G et al. 2001 Electrophysiological effects of dronedarone (SR 33589), a noniodinated amiodarone derivative in the canine heart: comparison with amiodarone. British Journal of Pharmacology 133 625-634.

Weiss RE, Murata Y, Cua K, Hayashi Y, Seo H \& Refetoff S 1998 Thyroid hormone action on liver, heart, and energy expenditure in thyroid hormone receptor beta-deficient mice. Endocrinology 139 4945-4952.

Weiss RE, Korcarz C, Chassande O, Cua K, Sadow PM, Koo E, Samarut J \& Lang R 2002 Thyroid hormone and cardiac function in mice deficient in thyroid hormone receptor-alpha or -beta: an echocardiograph study. American Journal of Physiology, Endocrinology and Metabolism 283 E428-E435.

Wikstrom L, Johansson C, Salto C, Barlow C, Campos BA, Baas F, Forrest D, Thoren P \& Vennstrom B 1998 Abnormal heart rate and body temperature in mice lacking thyroid hormone receptor alpha 1. EMBO Journal 17 455-461.

Yanagisawa M, Kurihara H, Kimura S, Goto K \& Masaki T 1988 A novel peptide vasoconstrictor, endothelin, is produced by vascular endothelium and modulates smooth muscle $\mathrm{Ca}^{2+}$ channels. Journal of Hypertension Supplement 6 S188-S191.

Zandieh DB, Platvoet-ter Schiphorst M, Van Beeren HC, Labruyere WT, Lamers WH, Fliers E, Bakker O \& Wiersinga WM 2002 TR(beta) 1 protein is preferentially expressed in the pericentral zone of rat liver and exhibits marked diurnal variation. Endocrinology 143 979-984.

Zandieh-Doulabi B, Dop E, Schneiders M, Schiphorst MP, Mansen A, Vennstrom B, Dijkstra CD, Bakker O \& Wiersinga WM 2003 Zonal expression of the thyroid hormone receptor alpha isoforms in rodent liver. Journal of Endocrinology 179 379-385.

Zhang XY, Kaneshige M, Kamiya Y, Kaneshige K, McPhie P \& Cheng SY 2002 Differential expression of thyroid hormone receptor isoforms dictates the dominant negative activity of mutant beta receptor. Molecular Endocrinology 16 2077-2092.

Received in final form 19 December 2005

Accepted 17 January 2006

Made available online as an Accepted Preprint 15 February 2006 